\title{
Is there Shalom, or Not? Jeremiah, a Prophet for South Africa*
}

\author{
GEORG FiSCHER SJ (UNIVERSITY OF INNSBRUCK) ${ }^{1}$
}

\begin{abstract}
:
There is a dispute between prophets about the status of Jerusalem and its society. The Book of Isaiah, on various occasions, sees the city and its people full of shalom "peace, wellbeing" (Isa 26:3; 32:18). The Book of Jeremiah, on the other hand, negates such a vision and accuses colleagues announcing such a message of "deceit" (Jer 6:13-14). The book is outstanding in its focus on the grievances leading to the fall of Jerusalem; its profile is marked by calling things as they are, analyzing the roots of evil, and disclosing the broken relationship with God as one of the causes. Such a critique has consequences: Jeremiah has to suffer, more than any other colleague. Nevertheless he, too, proclaims shalom (e.g. Jer 29:11), but it is rooted in a new perception of an inwardly touched God who desires eagerly to bring about a change to those who have gone through hardship. This message of the Book of Jeremiah and the figure of the prophet have a bearing for South Africa: suffering, problems, injustice can all be resolved, if they are addressed in a manner similar to the way in which Jeremiah dared to speak out and to advocate God's view in his own times.
\end{abstract}

Keywords: shalom, suffering, hope, critique, conflict literature

\section{A INTRODUCTION}

"No more will violence (חמס) be heard in your country, oppression and collapse (שד ושבר) in your borders . . .," Isa 60:18 states with reference to Jerusalem. The Book of Jeremiah ${ }^{2}$ does not share this opinion. It views Jerusalem as a well that constantly brings forth evil so that "violence and

* To cite: Georg Fischer, "Is there Shalom, or Not? Jeremiah, a Prophet for South Africa," OTE 28, no.2 (2015): 351-370. DOI: http://dx.doi.org/10.17159/2312$3621 / 2015 / \mathrm{v} 28 \mathrm{n} 2 \mathrm{a} 8$

1 Research associate Department of Old Testament Studies, Faculty of Theology, University of Pretoria. - This article is based on a paper read at the "Jeremiah Symposium" of the project "Prophetic Studies" (ProProf) at the University of Pretoria on $2^{\text {nd }}$ of September 2014, as part of the collaboration with that institution. I am especially grateful to Alphonso Groenewald for the invitation and the great hospitality. I would also like to thank Mrs. Felicity Stephens for the correction of the English of this article.

2 The Book of Jeremiah will from here on be abbreviated to "Jer," whereas "Jeremiah" will be used for the prophet. 
oppression (חמס ושד) are heard in her" (Jer 6:7). ${ }^{3}$ This is one of several instances where Jer runs counter to statements and positions of the Book of Isaiah $^{4}$ and thus mirrors a conflict between these two prophetic books. Isa perceives the future condition of Jerusalem as full of salvation and praise, ${ }^{5}$ Jer accentuates the desolate state of the city and testifies to problems and wounds in the society.

In this respect, namely in looking at the "dark side" of the community, Jer is unique. It is the longest single book of the Bible, and most of it deals with disaster. From beginning ${ }^{6}$ to end, Jer focuses at length on troubles and evils, more than any other book of the Bible. The expression מגור מסביב "Terror around!" is typical of $\mathrm{Jer}^{8}$ and of its perception of the city's situation.

What happens to Jerusalem and its inhabitants, and what they do, affects the prophet, too. When a society perishes, individuals are also affected, and so is Jeremiah. He confesses this in a wordplay: על־שבר בת־עמי השברתי a am broken because of the brokenness of the daughter-my people" (Jer 8:21). ${ }^{9}$

If we compare the conditions described in Jer with the present situation in South Africa, we can see some parallels. There are divisions and problems in

3 Cf. also Jer 20:8; therein, in the last "confession," Jeremiah declares: "As often as I speak, I have to cry out; 'Violence and oppression!' I have to shout."

4 Georg Fischer, "Partner oder Gegner? Zum Verhältnis von Jeremia und Jesaja," in „Sieben Augen auf einem Stein“ (Sach 3,9): Studien zur Literatur des Zweiten Tempels: Festschrift für Ina Willi-Plein zum 65. Geburtstag (ed. Friedhelm Hartenstein and Michael Pietsch; Neukirchen: Neukirchener Verlag, 2007), 69-79, republished as Georg Fischer, "Partner oder Gegner? Zum Verhältnis von Jeremia und Jesaja," in Der Prophet wie Mose: Studien zum Jeremiabuch (ed. Georg Fischer; BZABR 15; Wiesbaden: Harrassowitz, 2011), 188-199.

5 See the continuation in Isa 60:18: “. . . and you will call your walls ישועה and your gates תחלה."

6 Jer 1:3 already mentions the exile, Jer 1:14 disaster approaching from the North, Jer 1:16 divine judgment because of Jerusalem's evils.

7 Jer 52 is an adaptation of 2 Kings 24:18-25:30 and relates Jerusalem's fall in 587 B.C.E and its consequences.

8 Out of six occurrences, Jer has five: Jer $6: 25 ; 20: 3,10 ; 46: 5 ; 49: 29$. The only other instance, Ps 31:14, is dependent on Jer 20:10, cf. Eberhard Bons, Psalm 31 - Rettung als Paradigma (FTS 48; Frankfurt: Josef Knecht 1994), 113.

9 The speaker of this verse (and of the two following verses) is not identified, as often in Jer (see e.g. 4:19; 8:18; 10:19, 23). However, the "I" reacts here to the previously described disastrous situation of the people, and to understand it in reference to the prophet is the most probable solution. Another option would be to refer it to God who speaks at the end of 8:19, and once again from 9:1 [Hebrew; English 9:2] onwards. The word for "brokenness" is the same as the one translated in Isa 60:18 as "collapse"; this is another (contrasting) link with that passage. In any case, the "I" here functions as a kind of "reflector figure," serving to express the reaction when faced with such ruin. It may thus stand for Jeremiah as well as for anybody else, readers included. 
the society of this country, and many individuals have difficulty in escaping violence, in finding work, in living peacefully together. Similarly Jer viewed and reflected on what had happened earlier, to and in Jerusalem. So it is my hope, that Jer might have something to say for South Africa today.

I will present three aspects: the perception of the society (B), the suffering of individuals (C), and hope (D).

\section{B PERCEPTION OF THE SOCIETY IN THE BOOK OF JEREMIAH}

\section{Indications of the Present State}

One of the first tasks assigned to Jeremiah is mentioned in Jer 1:10: He has to "tear down and to pluck up and to destroy and to pull down, to build and to plant." The first four verbs indicate negative, destructive activities, double the number of the following two positive verbs. This offers, early in the book, a clue to the prophet's mission and his book's orientation. "Clearing the ground," purifying city and people from what is skewed, false and evil, is a necessary first step for a renewal of the community.

This orientation continues throughout the whole book. ${ }^{10}$ God confronts Jerusalem in Jer 2. He accuses her of infidelity and idolatry (e.g. 2:11, 27). In Jer 7 he calls the temple a "den of robbers" (7:11) because of the iniquities of those trying to hide there, and announces to his house the same fate as to his former sanctuary in Shiloh (7:14). In Jer 11:10-11 he states that the people have broken the covenant and declares that he will bring evil upon them. These accusations are more general, referring to a large part of or to the whole of the community.

Other passages demonstrate the sinfulness of individuals or groups. In Jer 5 Jeremiah had to seek for one doing justice that God might spare the city. As he did not find anybody among the דלים "the low ones," he turns to הגדלים "the great / influential ones," with the same result (5:4-5). Jeremiah 34:8-10 describes a release of slaves by the officials and the people ${ }^{11}$ in Jerusalem; yet in the next verse (v. 11) this is revoked, and the former dependence of the slaves is re-established. God reacts harshly to this (34:12-22).

These and many other texts demonstrate clearly that there is no שלום "shalom / peace / wellbeing" (Jer 6:14) ${ }^{12}$ in this society. The situation of

10 In the following I can only give a few examples, as this and the other themes are broadly developed in Jer I will restrict myself to just a few indications.

11 It must have been the group of the rich who could afford slaves in their household.

12 Hendrik Leene, "Blowing the Same Shofar: An Intertextual Comparison of Representations of the Prophetic Role in Jeremiah and Ezekiel," in The Elusive Prophet: The Prophet as a Historical Person, Literary Character and Anonymous Artist (ed. Johannes C. de Moor; OtSt 45; Leiden: Brill, 2001), 175-198, especially 177-183, sees the passage in Jer dependent on Ezek 13:10. 
Jerusalem and its people is desolate: the city is besieged, its community is divided, and the admonitions of God and his prophet Jeremiah are not heard. Disaster is impending.

\section{The Rejection of God}

One of the main reasons for the dire conditions of the people, according to Jer, is their turning away from God. He accuses Jerusalem and its population of having forsaken and even forgotten him (Jer 2:13, 32). They מאס "despise" his Torah and his word $(6: 19 ; 8: 9)$. An attitude of refusal is characteristic for them; the verb מאן "to reject, decline" occurs in various negatively connoted combinations, like "to refuse to become disciplined" (Jer 5:3), "to refuse to come back / return" (Jer 5:3; 8:5), ${ }^{13}$ "to refuse to know me" (9:5 [English v. $6]$ ), or "to refuse to listen to my words" (11:10).

Jer thus sees a religious origin for the desolate state of the society. The community's distance from God and refusal to obey his instructions and commandments are a major source of its disastrous political and social situation. This is mirrored also by the "absence" of God in 40:7-41:18, the description of Gedaliah's governorship and Ishmael's terror, and in 52:4-30, the destruction of Jerusalem in 587 B.C.E. ${ }^{14}$ Religious orientation and social behaviour are thus connected, and injustice and other grievances are often rooted in a disturbed relationship with God, as depicted here.

\section{Criticism is Necessary}

The evaluation of the society's situation differs greatly. Jeremiah 6:14, already quoted in part above, declares: שלום "And they tried to heal the brokenness of my people lightly, saying: 'Peace! Peace!' — but there is no peace!"15 The subject "they" refers to prophets and priests mentioned in the verse before, ${ }^{16}$ and they are very far from recognizing the dire reality of the situation, as the final remark of the verse, to

13 Hos 11:5 might have been the source for this expression.

14 The only references to YHWH in these passages are always connected with his "house" in Jer 41:5 and 52:13, 17, 20 where the temple is burned and emptied. In Jer 41 those making a pilgrimage to it are murdered by Ishmael.

15 The translation follows my German commentary, see Georg Fischer, Jeremia 1-25 (HTKAT; Freiburg: Herder, 2005), 257. The first verb has to be interpreted modally, as no real healing took place. The triple שלום is rendered here always with "peace," but it includes "well-being, salvation" as well. Jer 6:13-14 has a doublet in 8:10-11 and is thus emphasized. The doubling of שלום may refer to Isa 26:3 or 57:19, the only other instances where it is found as a prophet's utterance; in this case Jer would critically react to Isa (see above, the introduction, and note 4), challenging its optimistic outlook.

16 Both designations in Jer 6:13 are in the singular, referring to the respective groups; therefore they are understood here as plural. 
be attributed to God or the prophet, states. There is a strong opposition between the "wishful thinking" and illusionist estimation of the two main religious groups and Jeremiah's, or God's, assessment.

In Jer 6:13, the verse before, prophets and priests are accused of doing "deceit, treachery, deception." ${ }^{\text {"17 }}$ The deliberate creation of a false impression is a main theme of Jer, stretching from the first occurrence of this word in 3:10 where it is connected with a feigned return to God until its last occurrence in Jer 51:17, there attributed to idols. The bulk of usages, however, is associated with false prophets, as here in $6: 13 .{ }^{18}$ Jeremiah, more than any other prophet, exposes the falsity in the announcements of some of his prophetic colleagues and unveils also the falseness in the people's behaviour. ${ }^{19}$

Jer not only denounces them, it investigates the roots of such conduct. Jer 2, God's dispute with his people, tries to grasp what might be the cause of their turning away from him. Many times Jer charges them with guilt ${ }^{20}$ and attempts to convince them to שוב "return / convert,"21 reflecting also on the various backgrounds to the community's behaviour. ${ }^{22}$ However, all the efforts of the prophet do not succeed in effecting a change. ${ }^{23}$ He perceives the situation

17 שקר occurs 37 times in Jer, out of 119 in the Hebrew Bible; Jer has by far the most instances of this word.

18 is used in connection with indictments against other prophets also in Jer 5:31; 14:14; 20:6 and all instances in Jer 23 and 27-29; see the excursus in Fischer, Jeremia $1-25,190-191$.

19 For example swearing in Jer $5: 2 ; 7: 9$, in false confidence in $7: 4,8 ; 13: 25$, or speaking, in 9:2, 4.

${ }_{20}$ There are numerous passages, for example Jer $3: 1-2,6-10,13 ; 4: 18,22 ; 5: 7-8$, etcetera.

21 Jer uses שוב 112 times, more than any other book of the Bible (overall 1060 occurrences).

22 The desire to discover the reasons for the desolate state of the society becomes very visible in the literary technique of questions. Jer employs a unique form of it, with three elements, the last one introduced by מדוע "Why?" as in 2:14, 31; 8:4-5, 19, $22 ; 14: 19 ; 22: 28 ; 49: 1$. Besides this, it also uses many other questions, as in Jer 2:23, 28-29, 36; 3:1-2; 4:14, 21, $30 \ldots$

23 Barbara Green, Jeremiah and God's Plans of Well-Being (Columbia: University of South Carolina Press, 2013), 140, interprets this lack of success as an "apparent failure of the prophet." However, this misunderstands Jeremiah's mission (see the four negative verbs in Jer 1:10) endeavours and especially the overall outcome of his proclamation, namely a new, realistic hope and salvation, no longer based on illusions and falseness (cf. below, D). 
of the society as "broken," using the Hebrew term שבר. division characterize Jerusalem and its population. ${ }^{25}$

In many instances, Jeremiah attacks explicitly the leaders of the community: kings, officials, priests, prophets. He is outspoken in his critique, for example in denouncing King Jehoiakim of excessive luxury (Jer 22:14-15) and of making personal profit at the expense of those working for him $(22: 13,17)$; such grievances can also be observed with respect to political leaders in several countries at present. Similarly, Jer remembers the sins of former leaders. ${ }^{26}$ Even in direct personal exchange he dares ${ }^{27}$ to confront King Zedekiah (Jer 38:18, 21-23). God assigns explicitly to Jeremiah the role of a "tester,"28 and he gives his word in the prophet's mouth a new quality: it becomes "fire" (5:14), an apt comparison for the burning force of divine and prophetic criticism. ${ }^{29}$

What Jeremiah analyzed and proclaimed as God's messages did not produce a positive result in his lifetime. His book, however, testifies to a realistic perception and evaluation of the society at that time, in contrast to his contemporaries and several prophetic colleagues, and is thus an example of a critical voice raised against appeasing tendencies. Jer is hence a model for all those who view injustice and falsity, often hidden or veiled, within a society, and who dare to address such grievances, and thus renders an invaluable service.

\section{THE SUFFERING OF THE PROPHET JEREMIAH}

Anyone who sees evil denounces it and tries to change it will often encounter resistance or neglect, sometimes even persecution. For this reason, spiritual and, quite frequently, physical suffering is a kind of "natural" consequence of

24 Once again, Jer has more occurrences than any other biblical book, with 13 times as noun (out of 44) and 28 times as verb (out of 146 in the HB). The quote of Jer 8:21 above in the introduction shows that the prophet, or God, is similarly affected by it.

25 See above Jer 6:14, the attempted healing, further the passages in Jer 8:21; 10:19; $14: 17$. . 30:12, 15, and many others.

26 Jer 44:9 hints indirectly at King Solomon and his consorts, by asking: "Have you forgotten ... the evils of the kings of Judah and the evils of his wives?"

27 Having no fear is essential for such a confrontation. Jeremiah is exhorted and encouraged not to be frightened: Jer 1:8, 17-19; 15:20-21; see also his request in $17: 18$

28 Jer 6:27 uses the root בחן "to scrutinize, to prove" twice, once as a participle, indicating a profession, the second time as verb, for the activity expected from Jeremiah.

29 Two other passages use the same imagery for God's word: Jer 20:8 and 23:29; cf. Georg Fischer, "Das brennende Wort - An den Grenzen des Jeremiabuches," in Der Prophet wie Mose: Studien zum Jeremiabuch (ed. Georg Fischer; BZABR 15; Wiesbaden: Harrassowitz, 2011), 324-333. 
what became visible in A, and Jer attests that for Jeremiah, too. ${ }^{30}$ What this prophet had to suffer exceeds that of all his colleagues ${ }^{31}$ and becomes a case for linking him to Jesus. ${ }^{32}$ The painful experiences of Jeremiah also have relevance for South Africa, as they demonstrate the possible fate awaiting individuals who dare to challenge the mainstream or common opinions and to rise up against injustice - whereof South Africa has quite a number of outstanding examples in its recent history.

\section{Physical Hardship}

Several times Jer mentions that Jeremiah is taken into custody. The "prisons" at that time were not comparable to those of the present day; they could be cisterns which were no longer in use (Jer 38:6), the lower parts of houses (rather like cellars), storage rooms, or caverns (Jer 37:15-16), ${ }^{33}$ or a guarded courtyard, as indicated several times in Jer 32:2 to 39:14. Looking at South Africa, the imprisonment of Nelson Mandela and many others comes to mind.

Jeremiah's first reported performance of his ministry occurs only very late, in $19: 14-15,{ }^{34}$ and ends in disaster. Pashhur, a colleague as priest and prophet, overseer of the temple, beats ${ }^{35}$ him, puts him in the stocks, ${ }^{36}$ exposes

30 I addressed this motif already in an earlier article in the same journal: Georg Fischer, "Riddles of Reference: 'I' and 'We' in the Books of Isaiah and Jeremiah: The Relation of the Suffering Characters in the Books of Isaiah and Jeremiah," OTE 25 (2012): 277-291, especially 283-287, arguing for the dependence of the portrayal of the prophet Jeremiah on the "Servant Songs," in particular those in Isa 49 and 53. A much more extended version is: Georg Fischer, "Jeremiah, God's Suffering Servant," in Uomini e Profeti: Scritti in Onore di Horacio Simian-Yofre SJ (ed. Elzbieta M. Obara and Giovanni Paolo D. Succu; AnBib 202; Rome: Gregorian \& Biblical Press, 2013), 75-101. It develops broadly Jeremiah as the example of a "suffering prophet" (pp. 89-97).

31 No other prophet is depicted as having suffered so much as Jeremiah. The only other figure comparable to him might be Job; however, his suffering is "personal," concentrated in the first three chapters of the Book of Job and to occasional allusions to it in his speeches, whereas in Jer the prophet's pains are spread from the beginning right up to ch. 44, and are due to his task, being commissioned by God.

32 Cf. the answer of Jesus' disciples in Matt 16:14.

33 Othmar Keel, Die Welt der altorientalischen Bildsymbolik und das Alte Testament: Am Beispiel der Psalmen (3rd ed.; Darmstadt: Wissenschaftliche Buchgesellschaft, 1984), 61, illustration 78. The upper part of the cisterns or caves could be overhanging, thus impeding the prisoners to escape.

34 Rightly highlighted by Green, Jeremiah, 62: “. . . step out into his first 'live encounter' ..."

35 It might be that Pashhur did not beat Jeremiah personally, but let it be done by somebody else.

36 Shemaiah of Nehelam reminds the priest Jehoiada, in a letter sent to him in Jerusalem, from Babylon, that he is charged to intervene against mad people in the temple, 
him at a frequented gate ${ }^{37}$ and keeps him there overnight (Jer 20:1-3). This is torture and public humiliation, besides the pain or possible damage of the blows.

Jeremiah also starved. There are two indications of this, the first one in Jer 37:21 describing his daily provision of one loaf of bread in the courtyard. This is obviously an improvement on before, when he had stayed in the cells in the house of Jonathan (37:15-16) and had not received such treatment. The next reference to starving is Jer 38:9. The Kushite Ebed-Melech points out to King Zedekiah that Jeremiah "will die of hunger down there" in the cistern, and succeeds in pulling the prophet out of it and thus saving his life.

Jeremiah's suffering in his mission has an impact on his state of health, too. In his last "confession" he expresses his desperate situation: when he proclaims God's word, the consequence is disgrace and humiliation (Jer 20:8); if he does not, he has to sense a "burning fire" within himself (20:9). So he is caught in an impasse: he can never escape pain, be it in his role within the community, or be it in his personal feelings. Jeremiah's commissioning is inextricably linked with suffering, right from the beginning. ${ }^{38}$

\section{Mental Challenges}

The dead-end situation reported in the last confession reveals the inner struggles of Jeremiah. The interior suffering of the prophet had already started much earlier, in his very first utterance, where he reacts to God's sending him in Jer 1:6: אהה אדני יהוה "Alas! O Lord YHwh!"39 Jeremiah begins to speak with an expression of lament, and this will become typical of him in his book. The next dialogue with God, after the commissioning in Jer 1, is reported in 4:10; it has the same opening, but there it refers to the discrepancy between seemingly divine proclamation ${ }^{40}$ and the real situation. Lamentation characterizes Jeremiah, more than any other prophet, and leads also to those wonderful texts called "confessions," which add a new dimension to prayer.

to put them not only in the stocks, but even fetter them at the neck with jougs (צינק, Jer 29:26), and requests the same in the case of Jeremiah.

37 The Benjamin gate at the temple was the one leading to Jeremiah's home village of Anatoth. Therefore he could easily be recognized by those knowing him, and the "news" of his punishment could spread fast to his native village.

38 God informs Jeremiah in Jer 1:19 that others will fight against him. The earlier exhortations not to fear or to be frightened in 1:8, 17 allude to possible future confrontations.

39 Exactly the same wording can be found in Josh 7:7 and Judg 6:22, four times in Ezek, and again in Jer 4:10; 14:13; 32:17.

40 Jeremiah's accusation that God had deceived the people in 4:10 is clarified ten chapters later by YHWH's reply to his prophet in 14:13-14. There it becomes explicit that the announcement attributed to God in 4:10 refers to the statements of other prophets who falsely claim to be speaking in his name. 
There is an inner connection between Jeremiah's laments in the first ten chapters of the book and their continuation in the confessions. The latter can be seen as a kind of "natural progression" of the first element, as they intensify the relationship with God and critically address the burning issues. The severity of the prophet's conflicts leads to increased and deepened prayer. ${ }^{41}$

Jeremiah's commissioning seems to be a failure. He does not succeed in convincing or changing the people, in order to make them turn back to YHWH and avoid the catastrophe of Jerusalem's fall in 587 B.C.E.. Even after that disaster, his advice is neglected, and the people choose to leave the country and go down to Egypt (Jer 42-44). ${ }^{42}$ This is the last and final example that his message is neither heard nor followed, exactly as God had foretold. ${ }^{43}$

A unique feature of Jer is the prohibition of intercession. ${ }^{44}$ Jeremiah 18:20 "remember my staying before you to speak good over them" testifies to Jeremiah's former intercession; now the behaviour of the people has worsened so much that he is no longer allowed to do so. ${ }^{45}$ This means that an essential prophetic task (cf. also Amos 7:1-6), namely mediating between divinity and society, is forbidden to him.

41 Prayer has a key role within Jer. Various forms are present, and the confessions display a new, outspoken way of communicating with God. For the importance of prayer especially in Jer see Georg Fischer, "Gebete als hermeneutischer Schlüssel zu biblischen Büchern - am Beispiel von Jeremia," in Der Prophet wie Mose: Studien zum Jeremiabuch (ed. Georg Fischer; BZABR 15; Wiesbaden: Harrassowitz, 2011), 374-389, published originally as Georg Fischer, "Gebete als hermeneutischer Schlüssel zu biblischen Büchern - am Beispiel von Jeremia," in Congress Volume Ljubljana 2007 (ed. André Lemaire; VTSup 133; Leiden: Brill; 2010), 219-238.

42 "Egypt" plays a special role in Jer: Michael P. Maier, Ägypten - Israels Herkunft und Geschick: Studie über einen theo-politischen Zentralbegriff im hebräischen Jeremiabuch (ÖBS 21; Frankfurt: Lang, 2002). The dynamic of Jeremiah's prophetic career ends with these chronologically last appearances in Jer 42-44. The decision to flee to Egypt signifies a reversal of God's liberation from there in the Book of Exodus.

43 In Jer 7:23-24 YHwH had said that the people had not listened to his voice up to now, and announced shortly thereafter (v. 27) that they will not listen to Jeremiah, even when he calls aloud. Thus the prophet stays in solidarity with God, encountering the same rejection from the side of the community.

44 For this motif, see the comprehensive study of Benedetta Rossi, L'intercessione nel tempo della fine: Studio dell'intercessione profetica nel libro di Geremia (AnBib 204; Rome: Gregorian \& Biblical Press, 2013).

45 The prohibition is repeated thrice: Jer 7:16; 11:14, and 14:11, with a final explanation in 15:1, referring to Moses and Samuel as prophetic intercessors. 
A still greater challenge to Jeremiah is God's demand that he should live as a single man. The instruction in Jer 16:2 not to marry and not to have children runs counter to the divine command in Gen 1:28 (repeated in Gen 9:1) "to be fruitful and to multiply" and requests from the prophet an isolated lifestyle. This is further accentuated by the forbidden participation in communal events, even cases of mourning over the dead (Jer 16:5-8), as a sign of the end of any solidarity. ${ }^{46}$

Threats and accusations are another mark of Jeremiah's life. The men of his home village Anatoth face him with the choice of either ceasing to prophesy or being put to death (Jer 11:21). The reaction to his second temple sermon is to have a death sentence pronounced on him by priests, prophets and people (Jer 26:8). ${ }^{47}$ Jeremiah is falsely accused by the sentry Irijah in 37:12-14 of deserting to the Babylonian army. Shortly before Jerusalem's fall, King Zedekiah consults him, yet neglects his recommendation and threatens him with death should he reveal the contents of the dialogue (Jer 38:24).

The picture emerging here of the mental challenges to the prophet Jeremiah has parallels in South Africa. Some conditions are so bad and unjust that they cause lamentation and weeping and lead people to pray more intensely. Like Jeremiah in former times, critics today ${ }^{48}$ are also neglected, accused, threatened or silenced, in many countries of the world. They often have to live a solitary existence, full of inner struggles, and suffering from the impression that they have failed. Jer is an encouragement not to give up, but to continue along the path of truth and justice with the Lord.

\section{$3 \quad$ An Unparalleled Figure}

Who is this Jeremiah? The only access to this prophet is through the book carrying his name, which, certainly as a whole, is late. ${ }^{49}$ Jer portrays the figure of an outstanding prophet, in many respects. Jeremiah appears to be a kind of summary of several important precursors in Israelite history, incorporating various features of them in his profile.

First of all, he is presented as the promised successor to Moses, and equal to him. God had assured Moses in Deut 18:18: "I will rise up a prophet

46 The loneliness of the prophet is alluded to in the second confession, too: "I did not sit in the company of merrymakers and was joyful ..." (Jer 15:17).

47 The prophet's death is requested anew in the opening of the trial in 26:11, but the accusation is turned down by the officials and the people in 26:16.

48 Desmond Tutu in his recent critique of the ANC and of Robert Mugabe may be an example at present for what Jeremiah did in his time.

49 The manifold intertextual relationships with other biblical books which are used as sources in Jer do not allow dating it prior than the fourth century B.C.E.. This means that there is a gap of approximately 200 years between the prophet's life and the report about him in Jer. 
like you from the midst of their brothers, and I will put my words into his mouth . . . " This announcement is realized in the vocation of Jeremiah in Jer $1: 9$, the only instance in the HB where God is said to have "put my words into the mouth" of somebody. ${ }^{50}$ The linking of Jeremiah with Moses continues throughout the book, ${ }^{51}$ becoming explicit in God's final rejection of intercession for the people in Jer 15:1, where Samuel is also mentioned.

The visions in Jer 1:11-16 and Jer 24 are modelled upon those of the prophet Amos. ${ }^{52}$ God's question to him in Amos 8:2 and those to Jeremiah in Jer $1: 11,13$ are the same, and similarly the introduction to the first three visions in Amos 7:1, 4, 7 and Jer 24:1. Besides that, Jer often uses the proclamation of Amos as a source. ${ }^{53}$

In exposing "love" as a key to understanding God's change of heart and attitude towards his people, Jer follows another predecessor of Jeremiah, the prophet Hosea. Jer 2-3 and 31 are influenced by Hos 1-3 and 11 and draw on these chapters. ${ }^{54}$

In Jer 26:18 some elders quote the announcement of Jerusalem's destruction by the prophet Micah from Mic 3:12. This is the only case in the Latter Prophets where a colleague is mentioned by name. A sentence from the verse before, Mic 3:11 "no evil will come upon us," characterizes the illusionary confidence of some of Jeremiah's opponents in Jer 5:12, and the criticism of false prophets to "lead the people astray" links Jer 23:13 to Mic 3:5.

50 Renate Brandscheidt, “'Bestellt über Völker und Königreiche’ (Jer 1:10): Form und Tradition in Jeremia 1," in TTZ 104 (1995): 12-37, here 30, interprets the divine gesture of touching Jeremiah's mouth as enactment and dramatization of Deut 18.

51 The relationship between the two is, especially in the latter part of the book, one of contrast: Luis Alonso Schökel, "Jeremías como anti-Moisés," in De la Tôrah au Messie: études d'exégèse et d'herméneutique bibliques offertes à Henri Cazelles pour ses 25 années d'enseignement à l'Institut catholique de Paris, octobre 1979 (ed. Maurice Carrez, et al.; Paris: Desclée, 1981), 245-254. Christopher R. Seitz, too, links both prophets closely. See Christopher R. Seitz, "The Prophet Moses and the Canonical Shape of Jeremiah," ZAW 101 (1989): 3-27.

52 Walter Beyerlin, Reflexe der Amosvisionen im Jeremiabuch (OBO 93; Fribourg: Universitätsverlag, 1993).

53 Judith Pschibille, Hat der Löwe erneut gebrüllt? Sprachliche, formale und inhaltliche Gemeinsamkeiten in der Verkündigung Jeremias und Amos' (BThSt 41; Neukirchen: Neukirchener Verlag, 2001).

54 A. R. Pete Diamond and Kathleen O'Connor, "Unfaithful Passions: Coding Women Coding Men in Jeremiah 2-3 (4:2)," BibInt 4 (1996): 288-310; Richtsje Abma, Bonds of Love: Methodic Studies of Prophetic Texts with Marriage Imagery: Isaiah 50:1-3 and 54:1-10, Hosea 1-3, Jeremiah 2-3 (SSN 40; Assen: van Gorcum, 1999), among many others. 
God demands from Ezekiel that he "eat a scroll" (Ezek 2:8-3:3). The closest parallel is Jer 15:16 in the second confession of Jeremiah where the prophet says: "When your words were found, I ate them ...." The critique of other prophets, the saying in Ezek 18:2 // Jer 31:29, the role of the "watchman," the process of assaying, and many other motifs link Ezek and Jer. ${ }^{55}$ "Jeremiah," as portrayed in Jer, thus often seems to pick up themes of Ezekiel, his contemporary as a prophet. Mostly he alludes to them only briefly, enriching them with various other ideas.

Several connections with the Book of Isaiah have already been mentioned. Very strong relationships exist between the "Songs of the Servant of the Lord," especially Isa 49 and 53, and the first two confessions, Jer 11 and 15. The prophet Jeremiah appears therein as a realization of this suffering servant in Isa. ${ }^{56}$ The amount of pain and persecution Jeremiah has to bear is extraordinary and exceeds that of any other prophet.

The figure of "Jeremiah" stands obviously "in dialogue" 57 with other prophetic scrolls and important characters. His proclamation comprises a lot of motifs found elsewhere and brings them together into a synthesis on a higher level; for this reason, some of the texts in Jer, especially those in poetry, are like "mosaics." Jeremiah himself stands out as the only figure in the HB who claims to be the promised successor to Moses, in incorporating specific traits of some of his predecessors (Amos, Hosea, Micah, Isaiah), and in extending the physical and mental suffering to an extreme. "Nobody knows the trouble I've seen ..." is valid for many people in South Africa, and for Jeremiah, too.

\section{ANOTHER MESSAGE OF HOPE}

The negation of the double announcement of shalom by other prophets in Jer 6:14 // 8:11 could indicate that Jeremiah is opposed to such a positive perspective. It is true, that large portions of Jer have a somber tone and, read without seeing the overall dynamic, sound rather pessimistic. Nevertheless, just as all

55 Cf. Leene, "Blowing," and Dieter Vieweger, Die literarischen Beziehungen zwischen den Büchern Jeremia und Ezechiel (BEATAJ 26; Frankfurt: Lang, 1993); Vieweger, however, judges Jer to be prior to Ezek, a position which after the recent study of Hendrik Leene, Newness in Old Testament Prophecy (OtSt 64; Leiden: Brill, 2014) can no longer be upheld.

56 Fischer, "Jeremiah, God's." The reverse position is held by Katharine Dell, "The Suffering Servant of Deutero-Isaiah: Jeremiah Revisited," in Genesis, Isaiah, and Psalms: A Festschrift to Honour Professor John Emerton for his Eightieth Birthday (ed. Katharine Dell, Graham Davies and Yee Von Koh; VTSup 135; Leiden: Brill, 2010), 119-134.

57 This is also a significant result of the study of Silvana Manfredi, Geremia in dialogo: Nessi con le tradizioni profetiche e originalità in Ger 4,5-6,30 (FTS 6; Caltanissetta: Salvatore Sciascia, 2002). 
books of the latter prophets contain hope, Jer also offers expectations and promises of a better future. ${ }^{58}$ However the manner of doing so, and the contents are different in Jer.

\section{The Portrayal of God}

The main base and the principal source for hope in Jer is $Y H W H$. For the most part, it is his announcements and offers to the community that open a way out of the impasse into which the people have maneuvered themselves by breaking the covenant and being an "assembly of cheaters" (Jer 9:1). I can present here only some aspects of the rich portrayal of God in Jer. ${ }^{59}$

A unique feature of YHWH in Jer is his weeping. It is reported three times. In Jer 9:9 [English 9:10] he desires to weep over the mountains which have become desolate because of the deep-rooted falsity of his people. In Jer 14:17 the prophet is told to communicate from God that "tears flow down my eyes and do not stop night and day, because the virgin-daughter-my people is broken [with] great brokenness." ${ }^{60}$ The third time, God even weeps over a foreign nation, Moab (Jer 48:32). YHWH's tears are an expression of his inner commotion. He feels near to mountains, Israel, and Moab, and would like to rescue them; yet he is "helpless," so to speak ${ }^{61}$ as the community's behaviour impedes his intervention.

58 Jeremiah Unterman, From Repentance to Redemption: Jeremiah's Thought in Transition (JSOTSup 54; Sheffield: JSOT Press, 1987), 176-177, tries to divide the various positions regarding judgment and hope in Jer into three different time periods. In my view, they do not mirror these phases, but rather correspond to an overall plan linking salvation to the experience of suffering and divine change, granted undeservedly.

59 Walter Brueggemann, The Theology of the Book of Jeremiah (New York: Cambridge University Press, 2007), concentrates very much on the aspect of God's "sovereignty." This is correct, but equally true for many other biblical books. In my view, Jer displays many specific features that can be highlighted; for a broader presentation of what is dealt with here only briefly see Georg Fischer, Jeremia: Der Stand der theologischen Diskussion (Darmstadt: Wissenschaftliche Buchgesellschaft, 2007), 149160, and Georg Fischer, Theologien des Alten Testaments (NSKAT 31; Stuttgart: Katholisches Bibelwerk, 2012), 87-95.

60 The root שבר "break, brokenness" is used here twice and intensified by the adjective "great"; see B, 3 and note 24 above.

61 Once, in Jer 14:9, this is even addressed by the people in their prayer: "Why are you ... like a hero who is unable to help?" 
Divine affection finds extraordinary statements in the "scroll of consolation" (Jer 30-31). Upon the confession of the people "From afar YнwH has appeared to me" in 31:3, God ${ }^{62}$ immediately responds: ואהבת עולם אהבתיך "And with eternal love I have loved you." This is the only phrase within the HB that speaks of God's love as "eternal" and emphasizes this even further by the doubling of the root אהב "(to) love." In another confession, the one of Ephraim in 31:18-19, God reacts with a self-disclosure of his inner feelings: "Is Ephraim a dear son to me? Is he a child of delight, because, as often as I mention him, I cannot but remember him still? Therefore my bowels make noise for him; I must have compassion with him - oracle of YHWH." (31:20).

After these unique "emotional" divine traits I will present here three foci of Jeremian theology that are emphasized by their frequent repetition. The Hebrew verb שכם in the hip 'il in connection with another verb can be understood modally, as doing something "incessantly." from 7:13, 25 onwards and is, with one exception, exclusive to this book. ${ }^{64}$ God has, without disruption, and with all his energy, constantly spoken to his people and sent prophets - but to no avail. This shows his ongoing effort and zeal for the community's well-being. ${ }^{65}$

Still more, eleven times, ${ }^{66}$ the phrase שוב שבות "to turn a turning," or more freely "to restore the fortunes," is used in Jer. It indicates a fundamental change for the better, granted by God after a period of adversity and suffering. This takes up a promise of Moses (Deut 30:3) and applies it in Jer to those who have experienced evil and loss, starting with the ones exiled with King Jehoiachin in Jer 29:14, and ending once again with a foreign nation, this time Elam (Jer 49:39).

In inner connection, and as a precondition for such a restoration of the fortunes, God "forgives" (סלח) the iniquities of his people. This verb occurs six times in Jer. ${ }^{67}$ First, YHWH offers to pardon Jerusalem in the case that just one

62 The change of speaker is not indicated explicitly; however, the contents demands that we assume God is speaking in the second phrase. The missing introduction is a sign that he answers instantly.

63 Rüdiger Bartelmus, "haškem w ${ }^{e}$ lammed - die 'Unermüdlichkeitsformel' und die Etymologie von hiškim oder: Was hat engagiertes Lehren mit dem Beladen von Kamelen zu tun?" in Text, Methode und Grammatik: Wolfgang Richter zum 65. Geburtstag (ed. Walter Groß, et al.; St. Ottilien: EOS, 1991), 17-27.

64 The only other instance is $2 \mathrm{Chr} 36: 15$, which is dependent on Jer.

65 Twice God refers also to his being "vigilant": Jer 1:12; 31:28.

66 For the list of them see Hermann-Josef Stipp, Deutero-jeremianische Konkordanz (ATSAT 63; St. Ottilien: EOS, 1998), 130. The HB has 25 occurrences in all. Once again, Jer stands out as having the greatest number of them.

67 For comparison: All the other Latter Prophets have only two instances, namely Isa 55:7, and Amos 7:2. 
person doing right is found in it (Jer 5:1; cf. also 36:3); as this is not possible, he asks why he should forgive (5:7). Later on, of his own accord, he grants pardon nevertheless (Jer 31:34; 33:8; 50:20).

These unique features of YHWH in Jer make him different from all other "gods," for which Jer 10:1-16 is the key passage. Four times they and their devotees are opposed to the biblical God and his worshippers. ${ }^{68}$ YHWH is unequalled, and called "king of the nations" as well as אלהים אמת "God of truth / fidelity" (Jer 10:6-7, 10). ${ }^{69}$ God's unicity and internationality also become visible in his universal judgment (see especially Jer 25:15-38, and the oracles against the foreign nations in Jer 46-51). As he knows the "kidneys and hearts" (Jer 11:20; 20:12), he can be just therein.

Jer portrays $Y H W H$ in its own way. It attributes to him unique traits, for example his weeping and "eternal love," and accentuates some of his characteristics, like his eagerness in trying to motivate and convince his people, or his desire to bring about a change for good, even for other peoples. Despite the disastrous situation of Israel, Jer can thus foster hope, in directing the people's view towards their God, who alone can ameliorate their fate and is intent on doing so. This may be a source of confidence for South Africa, too: YHWH yearns to mend brokenness and establish anew justice and loyalty.

\section{$2 \quad$ "Plans of Shalom" (Jeremiah 29:11)}

The description of brokenness, the accusations of infidelity and the announcements of judgment are dominant in Jer. This conveys the impression that negative features prevail. However, the core of Jer's message and its dynamic point in another direction, namely to a new beginning after the catastrophe.

God has indicated this already in Jeremiah's vocation, in Jer 1:10. After the four verbs of destruction (see above B, 1) he entrusts him with the task "to build and to plant." From the beginning, even before the long disputes with the people, such a positive orientation is God's plan and final aim. The ruin of Judah and the devastation of Jerusalem are only an "intermediate phase" and a precondition for the construction and growth of a community on a solid, not a false basis.

The offers of and invitations to conversion are another indication of that direction of divine action. Even against his own law in Deut 24:1-4, God allows unfaithful Judah in Jer 3:1-4:4 to "return" $3: 12,14,22)$. He has already, earlier, exhorted the people to convert through

68 Jer 10:2-5, 8-9, 11, 14-15, present the other gods, their idols and their producers, in contrast to YHWH and his followers, depicted in 10:6-7, 10, 12-13, 16. This deliberate structure of Jer MT is dissolved in the Septuagint version.

69 Both concepts are common to the HB, but the exact expressions occur only here.

70 For שוב “to return" as a key motif in Jer see B, 3 with note 21. 
the prophets (Jer $25: 5 ; 35: 15),^{71}$ and he repeats this call later on in Jer 18:11. Ephraim's confession in 31:18 "Let me return, so that I may return!" may be regarded as a kind of "final" resolution" of this motif - God has succeeded in persuading Israel to come back to him.

YHWH even creates the preconditions for the people's conversion. In the vision of the fig baskets he promises to "give a heart to know me" (Jer 24:7), thus healing the sinful inclination and engraving of Jer 17:1. In the scroll of consolation he goes even beyond that by writing his Torah on the hearts (Jer 31:33) and thus making the people feel an inner concordance between divine law and personal intent.

The announcement in Jer 24 refers to those exiled with King Jehoiachin to Babylon, similarly to Jer 29 , with its letter to those in the Golah. ${ }^{73}$ In it God reveals what he expects from them (29:5-7) and what he is going to do with them (29:11-14), and his first message is מחשבות שלום "thoughts of shalom (peace / salvation / wellbeing)."74 The key word shalom rings a bell in Jer, bringing to mind the false proclamations of other prophets and Jeremiah's denial of such an evaluation of the state of the society $(6: 13-14 ; 8: 10-11$, see above B, 3 with note 15). Yet, the situation has now changed, and after the experience of military defeat, political breakdown and life in a foreign country the community is prepared to accept and appreciate God's generous offer of a renewed, intensive communion and bliss with him (29:12-14). YHWH has achieved his goal.

\section{E CONCLUSION}

The book of Jeremiah describes situations and experiences that are similar to those found in South Africa today and in its recent history, or which are not uncommon to it, in a manner that is unique in many respects. Jer is driven by the desire to see the problems from God's perspective and to analyze their roots, in order to find solutions. Such an attitude is opposed to an approach

71 Once, in Jer 15:19 God has to exhort even Jeremiah to convert, following the prophet's speaking of him as a "deceiving brook" in v. 18 .

72 Jer 31 is not the end of the book, but the scroll of consolation (Jer 30-31) envisages the outcome of divine dealings with Israel and thus shows their completion. It talks about future times (30:3 "behold, days are coming ...") and is thus set into a period after the book's ending in Jer 52 with the fall of Jerusalem in 587 B.C.E., and even after Babylon's ruin, spoken of in Jer 50-51.

73 The addressees of Jer 24 and 29 are a key to discovering God's "program": salvation is offered to those who have gone through and suffered the consequences of their former false behaviour. This experience can open them to a divine reshaping.

74 Green, Jeremiah, has aptly chosen this expression as title for her book. 
which tries to close the eyes to evils, to cover them up, to placate in situations of grave danger, or indeed to support villains and to whitewash their sins. ${ }^{75}$

The book of Jeremiah originated rather late, most probably centuries apart from the historical situation it deals with. This means that it uses the events before and around Jerusalem's fall in 587 B.C.E. as an example to address - indirectly - actual problems of the author's time. The lengthy confrontations with "false prophets" are a sign that Jer is "conflict literature,", engaged in opposing these other positions under the guise of a struggle which took place a long time ago. Making the effort to understand the irrational alienation from God and the people's infidelity (e.g. Jer 2:13) and to disclose these processes is a key concern of Jer.

With this orientation and emphasis, Jer is very relevant for today. The world is not "whole" (corresponding to shalom), but "broken" (cf. Jer's use of שבר (שר ), in various respects. The same is true for South Africa. It has a wealth of people, ideas, and a history of overcoming racial discrimination, yet there are many serious tensions even now. In such a situation, Jer is a stimulus and a challenge. It invites us to come to terms with the past, to analyze the roots of such injustice, and to find new ways of living together. ${ }^{77}$ Then there may be shalom, both as a society, and with God.

\section{BIBLIOGRAPHY}

Abma, Richtsje. Bonds of Love: Methodic Studies of Prophetic Texts with Marriage Imagery: Isaiah 50:1-3 and 54:1-10, Hosea 1-3, Jeremiah 2-3. Studia Semitica Neerlandica 40. Assen: van Gorcum, 1999. Alonso Schökel, Luis. "Jeremías como anti-Moisés." Pages 245-254 in De la Tôrah au Messie: études d'exégèse et d'herméneutique bibliques offertes à Henri Cazelles pour ses 25 années d'enseignement à l'Institut catholique de Paris, octobre 1979. Edited by Henri Cazelles, Maurice Carrez, Joseph Doré and Pierre Grelot. Paris: Desclée, 1981.

Bartelmus, Rüdiger. "haškem w $w^{e}$ lammed - die 'Unermüdlichkeitsformel' und die Etymologie von hiškim oder: Was hat engagiertes Lehren mit dem Beladen von Kamelen zu tun?" Pages 17-27 in Text, Methode und Grammatik:

75 This is one reason why Jer offers, more than any other book of the Bible, deals with so-called "false prophets" extensively and poignantly. Jer 23:17 gives an impression of such a behaviour as mentioned at the end. Morné Malan and Esias E. Meyer, "Jeremiah 26-29: A Not So Deuteronomistic Composition," OTE 27 (2014): 913-929, here 927, correctly observe the unique interest of Jer in this theme of false prophecy.

76 Jer is looking back into the past. What it describes is no longer acute; therefore the denomination "crisis literature" is only partially right. Some announcements of the Book of Isaiah seemed to furnish a major contrasting position to which Jer responded, cf. above the first paragraph of the introduction and B, 3 with note 15 .

77 The "Apartheid-museum" in Johannesburg is an impressive example for such a stance and endeavour. 
368 Fischer, “Is there Shalom?” OTE 28/2 (2015): 351-370

Wolfgang Richter zum 65. Geburtstag. Edited by Walter Groß, Hubert Irsigler, Wolfgang Richter and Theodor Seidl. St. Ottilien: EOS, 1991.

Beyerlin, Walter. Reflexe der Amosvisionen im Jeremiabuch. Orbis biblicus et orientalis 93. Fribourg: Universitätsverlag, 1993.

Bons, Eberhard. Psalm 31 - Rettung als Paradigma. Frankfurter Theologische Studien 48. Frankfurt: Josef Knecht 1994.

Brandscheidt, Renate. “'Bestellt über Völker und Königreiche' (Jer 1:10): Form und Tradition in Jeremia 1." Trierer theologische Zeitschrift 104 (1995): 1237.

Brueggemann, Walter. The Theology of the Book of Jeremiah. New York: Cambridge University Press, 2007.

Dell, Katharine. "The Suffering Servant of Deutero-Isaiah: Jeremiah Revisited." Pages 119-134 in Genesis, Isaiah, and Psalms: A Festschrift to Honour Professor John Emerton for his Eightieth Birthday. Edited by Katharine Dell, Graham Davies and Yee Von Koh. Vetus Testamentum Supplements 135. Leiden: Brill, 2010.

Diamond, A. R. Pete and Kathleen O'Connor. "Unfaithful Passions: Coding Women Coding Men in Jeremiah 2-3 (4:2)." Biblical Interpretation 4 (1996): 288-310.

Fischer, Georg. "Jeremiah, God's Suffering Servant." Pages 75-101 in Uomini e Profeti: Scritti in Onore di Horacio Simian-Yofre SJ. Edited by Elzbieta M. Obara and Giovanni Paolo D. Succu. Analecta Biblica 202. Rome: Gregorian \& Biblical Press, 2013.

"Riddles of Reference: 'I' and 'We' in the Books of Isaiah and Jeremiah: The Relation of the Suffering Characters in the Books of Isaiah and Jeremiah." Old Testament Essays 25 (2012): 277-291. . Theologien des Alten Testaments. Neuer Stuttgarter Kommentar: Altes Testament 31. Stuttgart: Katholisches Bibelwerk, 2012. Der Prophet wie Mose: Studien zum Jeremiabuch. Beihefte zur Zeitschrift für altorientalische und biblische Rechtsgeschichte15. Wiesbaden: Harrassowitz, 2011.

."Das brennende Wort - An den Grenzen des Jeremiabuches." Pages 324333 in Der Prophet wie Mose: Studien zum Jeremiabuch. Edited by Georg Fischer. Beihefte zur Zeitschrift für altorientalische und biblische Rechtsgeschichte 15. Wiesbaden: Harrassowitz, 2011.

."Gebete als hermeneutischer Schlüssel zu biblischen Büchern - am Beispiel von Jeremia." Pages 374-389 in Der Prophet wie Mose: Studien zum Jeremiabuch. Edited by Georg Fischer. Beihefte zur Zeitschrift für altorientalische und biblische Rechtsgeschichte 15. Wiesbaden: Harrassowitz, 2011. Published originally as Georg Fischer. "Gebete als hermeneutischer Schlüssel zu biblischen Büchern - am Beispiel von Jeremia." Pages 219-238 in Congress Volume Ljubljana 2007. Edited by André Lemaire. Vetus Testamentum Supplements 133. Leiden: Brill, 2010. . Jeremia: Der Stand der theologischen Diskussion. Darmstadt:

Wissenschaftliche Buchgesellschaft, 2007. 
."Partner oder Gegner? Zum Verhältnis von Jeremia und Jesaja.” Pages 69-79 in „Sieben Augen auf einem Stein“ (Sach 3,9): Studien zur Literatur des Zweiten Tempels: Festschrift für Ina Willi-Plein zum 65. Geburtstag. Edited by Friedhelm Hartenstein and Michael Pietsch. Neukirchen: Neukirchener Verlag, 2007. Republished as Georg Fischer, "Partner oder Gegner? Zum Verhältnis von Jeremia und Jesaja." Pages 188-199 in Der Prophet wie Mose: Studien zum Jeremiabuch. Edited by Georg Fischer. Beihefte zur Zeitschrift für altorientalische und biblische Rechtsgeschichte 15. Wiesbaden: Harrassowitz, 2011. Jeremia 1-25. Herders theologischer Kommentar zum Alten Testament. Freiburg: Herder 2005.

Green, Barbara. Jeremiah and God's Plans of Well-Being. Columbia: University of South Carolina Press, 2013.

Keel, Othmar, Die Welt der altorientalischen Bildsymbolik und das Alte Testament: Am Beispiel der Psalmen. 3rd ed. Darmstadt: Wissenschaftliche Buchgesellschaft, 1984.

Leene, Henk. Newness in Old Testament Prophecy: An Intertextual Study. Oudtestamentische Studiën 64. Leiden: Brill 2014. . "Blowing the Same Shofar: An Intertextual Comparison of Representations of the Prophetic Role in Jeremiah and Ezekiel." Pages 175198 in The Elusive Prophet: The Prophet as a Historical Person, Literary Character and Anonymous Artist. Edited by Johannes C. de Moor. Oudtestamentische Studiën 45. Leiden: Brill, 2001.

Maier, Michael P. Ägypten - Israels Herkunft und Geschick: Studie über einen theo-politischen Zentralbegriff im hebräischen Jeremiabuch. Österreichische biblische Studien 21. Frankfurt: Lang 2002.

Malan, Morné and Esias E. Meyer. "Jeremiah 26-29: A Not So Deuteronomistic Composition." Old Testament Essays 27 (2014): 913-929.

Manfredi, Silvana. Geremia in dialogo: Nessi con le tradizioni profetiche e originalità in Ger 4,5-6,30. Facoltà Teologica di Sicilia Studi 6. Caltanissetta: Salvatore Sciascia, 2002.

Pschibille, Judith. Hat der Löwe erneut gebrüllt? Sprachliche, formale und inhaltliche Gemeinsamkeiten in der Verkündigung Jeremias und Amos. Biblisch-theologische Studien 41. Neukirchen: Neukirchener Verlag, 2001.

Rossi, Benedetta. L'intercessione nel tempo della fine: Studio dell'intercessione profetica nel libro di Geremia. Analecta biblica 204. Rome: Gregorian \& Biblical Press, 2013.

Seitz, Christopher R. "The Prophet Moses and the Canonical Shape of Jeremiah." Zeitschrift für die alttestamentliche Wissenschaft 101 (1989): 3-27.

Stipp, Hermann-Josef. Deutero-jeremianische Konkordanz. Arbeiten zu Text und Sprache im Alten Testament 63. St. Ottilien: EOS, 1998.

Unterman, Jeremiah. From Repentance to Redemption: Jeremiah's Thought in Transition. Journal for the Study of the Old Testament: Supplement Series 54. Sheffield: JSOT Press, 1987. 
370 Fischer, "Is there Shalom?" OTE 28/2 (2015): 351-370

Vieweger, Dieter. Die literarischen Beziehungen zwischen den Büchern Jeremia und Ezechiel. Beiträge zur Erforschung des Alten Testaments und des antiken Judentum 26. Frankfurt: Lang, 1993.

Georg Fischer SJ, Theological Faculty of the University of Innsbruck, Department of Biblical and Historical Theology, Karl-Rahner-Platz 1, 6020 Innsbruck, Austria. Email: georg.fischer@uibk.ac.at. 